\title{
Homeobox genes: a molecular link between development and cancer
}

\section{Genes homeobox: uma relação molecular entre o desenvolvimento e o câncer}

\author{
Fabio Daumas Nunes* \\ Fernanda Campos Souza de Almeida** \\ Renata Tucci*** \\ Suzana Cantanhede Orsini Machado de Sousa****
}

\begin{abstract}
Homeobox genes are regulatory genes encoding nuclear proteins that act as transcription factors, regulating aspects of morphogenesis and cell differentiation during normal embryonic development of several animals. Vertebrate homeobox genes can be divided in two subfamilies: clustered, or HOX genes, and nonclustered, or divergent, homeobox genes. During the last decades, several homeobox genes, clustered and nonclustered ones, were identified in normal tissue, in malignant cells, and in different diseases and metabolic alterations. Homeobox genes are involved in the normal teeth development and in familial teeth agenesis. Normal development and cancer have a great deal in common, as both processes involve shifts between cell proliferation and differentiation. The literature is accumulating evidences that homeobox genes play an important role in oncogenesis. Many cancers exhibit expression of or alteration in homeobox genes. Those include leukemias, colon, skin, prostate, breast and ovarian cancers, among others. This review is aimed at introducing readers to some of the homeobox family functions in normal tissues and especially in cancer.
\end{abstract}

DESCRIPTORS: Genes, homeobox; Neoplasms; Growth \& Development.

RESUMO: Os genes homeobox são genes reguladores que codificam proteínas nucleares as quais atuam como fatores de transcrição, regulando vários aspectos da morfogênese e da diferenciação celular durante o desenvolvimento embrionário normal de diversos animais. Os genes homeobox de vertebrados podem ser subdivididos em duas famílias: os agrupados, ou HOX, e os não agrupados, ou divergentes. Durante as últimas décadas, vários genes homeobox, agrupados e não agrupados, foram identificados em tecidos normais, em células malignas e em diferentes doenças e condições metabólicas. Os genes homeobox estão envolvidos, por exemplo, no desenvolvimento normal do dente e em agenesias dentárias de ocorrência familiar. O desenvolvimento normal e o câncer têm muito em comum, já que ambos envolvem proliferação celular e diferenciação. A literatura tem mostrado um número cada vez maior de trabalhos relacionando os genes homeobox à oncogênese. Muitos tipos de câncer exibem expressão ou alteração nos genes homeobox. Eles incluem leucemias, câncer de cólon, pele, próstata, mama e ovário, entre outros. Esta revisão objetiva levar os leitores a conhecer algumas das funções da família homeobox nos tecidos normais e especialmente no câncer.

DESCRITORES: Genes homeobox; Neoplasias; Crescimento \& desenvolvimento.

\section{INTRODUCTION}

Homeobox genes are master development control genes that act at the top of genetic hierarchies regulating aspects of morphogenesis and cell differentiation in animals ${ }^{24}$. These genes were first discovered in the fruit fly Drosophila ${ }^{22}$ and identified as genes whose mutations cause body segment transformation, also known as homeotic transformation. This phenomenon consists of the transformation of one part of the body into another, e.g. a fly with four wings instead of two.

Homeobox family of genes encodes regulatory proteins controlling basic developmental processes in several tissues, including orofacial tissues ${ }^{33}$. They contain a common 180-nucleotide sequence (homeobox) coding for specific nuclear proteins (homeoproteins) that act as transcription factors. The homeobox sequence encodes a 60-aminoacid domain, the homeodomain, responsible for DNA binding ${ }^{8,11,32}$. Structural analyses have shown that the homeodomain consists of a helix-turn-helix motif that binds the DNA by inserting the recognition helix into the major groove of the DNA and its amino-terminal arm into the adjacent minor groove $^{13}$. The specificity of this binding allows homeoproteins to activate or repress the expression of batteries of downstream target genes ${ }^{21}$. Homeobox are also under regulation of some proteins, such as the

*PhD, Assistant Professor; **Dentist, Trainee; ***Doctorate Student; ****PhD, Associate Professor - Department of Oral Pathology, School of Dentistry, University of São Paulo. 
Nunes FD, Almeida FCS de, Tucci R, Sousa SCOM de. Homeobox genes: a molecular link between development and cancer. Pesqui Odontol Bras 2003;17(1):94-8.

signaling proteins Sonic hedgehog (SHH), fibroblast growth factor (FGF) and bone morphogenetic protein (BMP). The homeobox were shown to occur in all Metazoa, ranging from sponges to vertebrates and also plants and fungi ${ }^{6}$.

This review aims at introducing readers to some of the homeobox family functions in normal tissues and especially in cancer development, which could be of valuable clinical interest in the near future.

\section{HOMEOBOX GENES IN DEVELOPMENT}

The family of vertebrate homeobox genes can be divided in two subfamilies: a) the clustered homeobox genes, known as HOX genes or class I; and b) the nonclustered, or divergent homeobox genes.

The HOX family plays a fundamental role in the morphogenesis of vertebrate embryo cells, providing regional information along the main body axis ${ }^{11,24}$. This family is structurally and functionally homologous to the homeotic complex (HOM-C) of Drosophila. There are at least 39 genes in mice (HOX genes) and humans (HOX genes) organized in four genomic clusters of about $100 \mathrm{~kb}$ in length called HOX loci. Each cluster is located in a different chromosome (HOX-A, HOX-B, HOX-C and HOX-D, respectively at $7 \mathrm{p}, 17 \mathrm{p}, 12 \mathrm{p}$ and $2 \mathrm{p})$ and comprises 9 to 11 genes arranged in a homologous sequence organization (Figure 1$)^{7,8}$. HOX genes have been reported as implicated in angiogenesis and wound repair ${ }^{36}$, in functions of the female reproductive tract $^{35}$, and in pulmonary hypertension and emphysema $^{14}$. Mutations in HOX genes may yet participate in human malformations, e.g., HOXA13 generate the hand-foot-genital syndrome ${ }^{15}$, HOXB1 generate the Mowat-Wilson syndrome ${ }^{39}$, and Duanes Retraction Syndrome (DRS) links to the HOXD cluster ${ }^{1}$. Also, Ingram et al. ${ }^{16}$ (2000) reported evidence of an interaction between HOXA1, HOXB1, and gender in susceptibility to autism spectrum disorders.

The nonclustered genes are a large number of genes scattered throughout the genome that, never- theless, can be organized in distinct families based on their homologies and functional similarities. Some of the families include paired (PAX), orthodenticle (OTX), muscle segment (MSX), distalless (DLX), caudal (CDX), and empty spiracles (EMX) homeobox genes, among others $^{24}$.

During the last decades, several homeobox genes, clustered and nonclustered, were identified in normal tissue, in malignant cells, and in different diseases and metabolic alterations ${ }^{7}$. PAX genes are the homeobox family with the strongest connections with human diseases. PAX2 has been implicated in breast cancer ${ }^{34}$, renal hypoplasia and renal disease ${ }^{26}$; PAX3 has a role in rhabdomyosarcomas $^{2}$ and melanomas ${ }^{31}$; PAX5 determines the identity of $\mathrm{B}$ cells ${ }^{28}$. MSX homeobox genes are involved in the normal teeth development and in familial teeth agenesis ${ }^{9}$.

\section{HOMEOBOX AND CANCER}

Oral cancer is, respectively, the fifth and seventh most common cancer for male and female in the general population. About half of the patients afflicted will die within five years of diagnosis ${ }^{38}$. Squamous cell carcinomas account for $96 \%$ of all oral cancers. During the last decade, much progress has been made in delineating the molecular alterations that lead to oncogenic transformation ${ }^{11}$. Several studies indicate that alcohol and tobacco use are important factors causing oral cancer ${ }^{19,38}$. A genetic predisposition has been suggested, since the majority of the population exposed to the mentioned risk factors does not develop oral cancer. Also, sporadic cases of oral cancer occur in young adults, non-users of any identifiable carcinogen, and there have been reports of family history involvement ${ }^{23}$. Today, many genetic events caused by chromosomal alterations or mutations have been proposed to underline the progression of oral tumors ${ }^{38}$. The development regulatory genes ${ }^{4,11}$ are an important group of genes involved with carcinogenesis. These genes were never associated

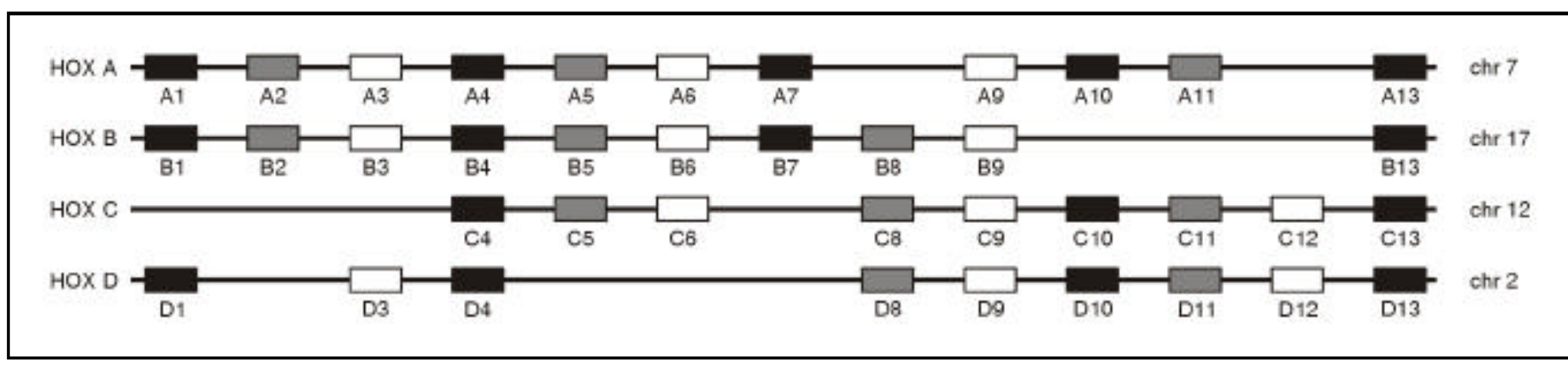

FIGURE 1 - Schematic representation of the four HOX (Class I) loci aligned according to the position on a different chromosome. 
Nunes FD, Almeida FCS de, Tucci R, Sousa SCOM de. Homeobox genes: a molecular link between development and cancer. Pesqui Odontol Bras 2003;17(1):94-8.

with oral cancer. Recently, we were able to show that four distinct squamous cell carcinoma cell lines express HOX genes differently from the control cells and tissue $^{27}$.

Cancer and normal development have a great deal in common, as both processes involve shifts between cell proliferation and differentiation ${ }^{4}$. Recent research has demonstrated that improper regulation of development genes may result in cancer. However, there is a lot to be learned about the interplay that exists between development, cell cycle, apoptosis and cancer.

Many cancers exhibit expression or alteration in homeobox genes. They include leukemia, colon, skin, prostate, breast and ovary cancers, among others. Recently it was shown that loss of expression in human breast cancer of p53, a gene that protects cells against malignant transformation, may be primarily due to lack of expression of HOXA $5^{29}$. However, the precise mechanisms by which homeobox gene alterations lead to cancer are still unknown ${ }^{11}$.

The demonstration of cell lineage-specific patterns of HOX gene activation in human and murine leukemic cell lines supports the hypothesis that HOX gene expression can regulate normal hematopoietic differentiation $^{21}$. Altered expression of HOX genes located in HOXA and HOXB loci is often involved in leukemogenesis. The infection of normal marrow cells with a LTR/HOXB8 construct, together with the action of the IL-3 gene, was able to induce myeloid leukemia in mice $^{24}$.

A genomic fusion in frame between the nucleoporin gene NUP98 and the HOXA9 gene was shown in three patients with myeloid leukemia and translocation $\mathrm{t}(7 ; 11)^{25}$. Chimeric fusion proteins resulting from the transcription activator domain of one protein and the DNA binding domain of another display a high oncogenic potential. Other fusions, as PBX1 to E2A and HRX to nuclear proteins, alter the sequence-specific binding of HOX genes, direct homeoproteins to a different target, and induce leukemogenesis ${ }^{19}$. The locus HOXC is mainly implicated in lymphomas. HOXC4, C5 and C6 are ex pressed in non-Hodgkin lymphom s, displaying a typeand site-restricted expression pattern in both T- and B-cell non-Hodgkin lymphomas ${ }^{3}$.

Major differences in HOX gene expression are detectable in primary solid tumors (kidney, colon, breast, prostate and smal cell lung cancer) compared with the corresponding normal adult organs ${ }^{7,20}$. Misexpression of HOX genes is detectable in metastatic lesions related to the primary tumor of origin and the corresponding normal tissue, supporting the hypothesis of an implication of homeoproteins in cancer evolution ${ }^{10}$.

Overexpression of the homeobox gene HSIX1 in MCF7 cells abrogated the G2 cell cycle checkpoint in response to X-ray irradiation, as it was observed with HOX11. Furthermore, HSIX1, as HOX11, is aberrantly expressed in cancer. Overexpression of HSIX1 is observed in $44 \%$ of primary and $90 \%$ of metastatic breast lesions, suggesting that HSIX1 may play a role in the progression of breast cancer ${ }^{11}$. In mammary glands, HOXC6 transcripts, which are active during the puberty and maturity, became silent during pregnancy, probably because of the negative regulation of steroid hormone, and are also inactive in mammary adenocarcinomas ${ }^{12}$.

In other neoplasms, expression of HOX genes was also reported. For instance, renal adenocarcinomas consistently express the HOXA9 gene and only rarely express either HOXD10 or HOXC9 ${ }^{30}$. HOXB6, HOXB8 and HOXC9 are misexpressed at various stages of colon cancer evolution ${ }^{37}$. HOXB7 is silent in normal melanocytes, but became active in melanomas ${ }^{5}$. In mouse skin, HOXA6, A7 and B7 were identified in papilloma, but not in normal skin ${ }^{6}$. HOXC6, D1 and D8 are expressed in human neuroblastoma cells ${ }^{8}$. Finally, in osteosarcomas, HOXC6 expression seems to be regulated by members of the TGF- $\beta$ superfamily ${ }^{18}$.

\section{CONCLUSIONS}

A link between development and cancer is expected since both processes involve cell proliferation and cell differentiation. Homeobox genes were first described in organisms in development and are now recognized to be expressed in many types of cancers. The difference between the expression pattern in distinct normal tissues and in tumor tissues must be further characterized in order to all in carcinogenesis. Also, further characterization isences of modulating these genes expression in neoplasms, including oral cancer.

\section{ACKNOWLEDGEMENTS}

The research is funded by Grants $97 / 13228-5$ and 01/13644-6 from FAPESP - Fundação de Amparo à Pesquisa do Estado de São Paulo. 
Nunes FD, Almeida FCS de, Tucci R, Sousa SCOM de. Homeobox genes: a molecular link between development and cancer. Pesqui Odontol Bras 2003;17(1):94-8.

\section{REFERENCES}

1. Appukuttan B, Sood R, Ott S, Makalowska I, Patel RJ, Wang $\mathrm{X}$, et al. Isolation and characterization of the human homeobox gene HOX D1. Mol Biol Rep 2002;27:95-201.

2. Barber TD, Barber MC, Tomescu O, Barr FG, Ruben S, Friedman TB. Identification of target genes regulated by PAX3 and PAX3 - FKHR in embryogenesis and alveolar rhabdomyosarcoma. Genomics 2002;79:278-84.

3. Bij1 JJ, van Oostveen JW, Walboomers JM, Horstman A, van den Brule AJ, Willemze R, et al. HOXC4, HOXC5 and HOXC6 expression in no-Hodgking's lymphoma: preferential expression of the HOXC5 gene in primary cutaneous anaplastic T-cell and oro-gastrointestinal tract mucosa-associated B-cell lymphomas. Blood 1997;90:4116-25.

4. Caldas C, Aparicio S. Cell Memory and cancer - the history of the trithorax and Polycomb group genes. Cancer Metastasis Rev 1999;18:313-29.

5. Care A, Silvani A, Meccia E, Mattia G, Stoppacciaro A, Parmiani G, et al. HOXB7 constitutively activates basic fibroblast growth factor in melanomas. Mol Cell Biol 1996;16:4842-51.

6. Chang PY, Kozono T, Chida K, Kuroki T, Huh N. Differential expression of Hox genes in multistage carcinogenesis of mouse skin. Biochim Biophys Res Commun 1998; 248:749-52.

7. Cillo C, Cantile M, Faiella A, Boncinelli E. Homeobox genes in normal and malignant cells. J Cell Physiol 2001;188:161-9.

8. Cillo C, Faiella A, Cantile M, Boncinelli E. Homeobox genes and cancer. Exp Cell Res 1999;248:1-9.

9. Davideau JL, Demri P, Hotton D, Gu TT, MacDougall M, Sharpe $\mathrm{P}$, et al. Comparative study of MSX-2, DLX-5, and DLX-7 gene expression during early human tooth development. Pediatr Res 1999;46:650-6.

10. De Vita G, Barba P, Odartchenko N, Givel JC, Freschi G, Bucciarelli G, et al. Expression of homeobox-containing genes in primary and metastatic colorectal cancer. Eur J Cancer 1993;29A:887-93.

11. Ford HL. Homeobox genes: a link between development, cell cycle, and cancer. Cell Biol Int1998;22:397-400.

12. Friedmann Y, Daniel CA, Strickland P, Daniel CW, Strickland P. Hox genes in normal and neoplastic mouse mammary gland. Cancer Res 1994;54:5981-5.

13. Gehring WJ, Muller M, Affolter M, Percival-Smith A, Billeter M, Qian YQ, et al. The structure of the homeodomain and its functional implications. Trends Genet 1990;6:323-9.

14. Golpon HA, Geraci MW, Moore MD, Miller HL, Miller GJ, Tuder RM, et al. HOX genes in human lung: altered expression in primary pulmonary hypertension and emphysema. Am J Pathol 2001;158:955-66.

15. Goodman FR, Scambler PJ. Human HOX gene mutations. Clin Genet 2001;59:1-11.

16. Ingram JL, Stodgell CJ, Hyman SL, Figlewicz DA, Weitkamp LR, Rodier PM. Discovery of allelic variants of HOXA1 and HOXB1: genetic susceptibility to autism spectrum disorders. Teratology 2000,62:393-405.

17. Katz MR, Irish JC, Devins GM, Rodin GM, Gullane PJ. Reliability and validity of an observer-rated disfigurement scale for head and neck cancer patients. Head Neck 2000; 22:132-41.

18. Kloen P, Visker MH, Olijve W, van Zoelen EJ, Boersma CJ. Cell-type specific modulation of Hox gene expression by members of the TGF-beta superfamily: a comparison bet- ween human osteossarcoma and neuroblastoma cell lines. Biochem Biophys Res Commun 1997;233:365-9.

19. Knoepfler PS, Kamps MP. The highest affinity DNA element bound by Pbx complexes in $t(1 ; 19)$ leukemic cells fails to mediate cooperative DNA-binding or cooperative transaction by E2a-Pbx 1 and class I Hox proteins - evidence for selective targetting of E2a-Pbx1 to a subset of Pbx-recognition elements. Oncogene 1997;14:2521-31.

20. Lawrence HJ, Sauwageau G. The role of HOX homeobox genes in normal and leukemic hematopoiesis. Stem Cells 1996; 14:281-91.

21. Levine M, Hoey T. Homeobox proteins as sequence-specific transcription factors. Cell 1988;55:537-40.

22. Lewis EB. A gene complex controlling segmentation in Drosophila. Nature 1978;276:565-70.

23. Llewellyn CD, Johnson NW, Warnakulasuriya KA. Risk factors for squamous cell carcinoma of the oral cavity in young people - a comprehensive literature review. Oral Oncol 2001;37:401-18.

24. Mark M, Rijli FM, Chambon P. Homeobox genes in embryogenesis and pathogenesis. Pediatr Res 1997;42:421-9.

25. Nakamura T, Largaespada DA, Lee MP, Johnson LA, Ohyashiki K, Toyama K, et al. Fusion of the nucleoporin gene NUP98 to HOXA9 by the chromosome translocation $\mathrm{t}(7 ; 11)(\mathrm{p} 15 ; \mathrm{p} 15)$ in human myeloid leukemia. Nat Genet 1996;12:154-8.

26. Nishimoto K, Iijima K, Shirakawa T, Kitagawa K, Satomura $\mathrm{K}$, Nakamura $\mathrm{H}$, et al. PAX2 gene mutation in a family with isolated renal hypoplasia. J Am Soc Nephrol 2001; 12:1769-72.

27. Nunes FD; Tucci R, Matizonkas LF, Pinto Júnior DS. Expression of the HOX genes in oral squamous cell carcinoma cell lines [submitted to publication].

28. Nutt SL, Eberhard D, Horcher M. Pax5 determines the identity of $\mathrm{B}$ cells from the beginning to the end of B-lymphopoiesis. Int Rev Immunol 2001;20:65-82.

29. Raman V, Martensen SA, Reisman D, Evron E, Odenwald WF, Jaffee E, et al. Compromised HOXA5 function can limit p53 expression in human breast tumours. Nature 2000;405:974-8.

30. Redline RW, Neish A, Holmes LB, Collins T. Homeobox genes and congenital malformations. Lab Invest 1992;66:773-82.

31. Scholl FA, Kamarashev J, Murmann OV, Geertsen R, Dummer R, Schafer BW. PAX3 is expressed in human melanomas and contributes to tumor cell survival. Cancer Res 2001;61:823-6.

32. Scott GA, Goldsmith LA. Homeobox genes and skin development: a review. J Invest Dermatol 1993;101:3-8.

33. Sharpe PT. Homeobox genes and orofacial development. Connect Tissue Res 1995;32:17-25.

34. Silberstein GB, Dressler GR, Van Horn K. Expression of the PAX2 oncogene in human breast cancer and its role in progesterone-dependent mammary growth. Oncogene 2002; 21:1009-16.

35. Taylor HS. The role of HOX genes in the development and function of the female reproductive tract. Semin Reprod Med 2000;18:81-9.

36. Uyeno LA, Newman-Keagle JA, Cheung I, Hunt TK, Young DM, Boudreau N. Hox D3 expression in normal and impaired wound healing. J Surg Res 2001;100:46-56. 
Nunes FD, Almeida FCS de, Tucci R, Sousa SCOM de. Homeobox genes: a molecular link between development and cancer. Pesqui Odontol Bras 2003;17(1):94-8.

37. Vider BZ, Zimber A, Hirsch D, Estlein D, Chastre E, Prevot $\mathrm{S}$, et al. Human colorectal carcinogenesis is associated with deregulation of homeobox gene expression. Biochem Biophys Res Commun 1997;232:742-8.

38. Wong DT, Todd R, Tsuji T, Donoff RB. Molecular biology of human oral cancer. Crit Rev Oral Biol Med 1996;7:319-28.
39. Zweier C, Albrecht B, Mitulla B, Behrens R, Beese M, Gillessen-Kaesbach G, et al. "Mowat-Wilson" syndrome with and without Hirschsprung disease is a distinct, recognizable multiple congenital anomalies-mental retardation syndrome caused by mutations in the zinc finger homeobox 1B gene. Am J Med Genet 2002;108:177-81.

Recebido para publicação em 10/07/02 Enviado para reformulação em 08/11/02 Aceito para publicação em 12/11/02 